\title{
Mesenchymal stromal cells as a choice for spinal cord injury treatment
}

\author{
Letícia Fracaro', Bernardo Zoehler², Carmen Lúcia Kuniyoshi Rebelatto \\ ${ }^{1}$ Core for Cell Technology, School of Medicine, Pontifical Catholic University of Paraná, Curitiba, 80215-200, Brazil. \\ ${ }^{2}$ Department of Genetics, Federal University of Paraná, Curitiba, 81531-980, Brazil.
}

Correspondence to: Dr. Letícia Fracaro, Pontifical Catholic University of Paraná, Core for Cell Technology, School of Medicine, Rua Imaculada Conceição, 1155, Curitiba, 80215-200, Brazil. E-mail: leticiafracaro@gmail.com

How to cite this article: Fracaro L, Zoehler B, Rebelatto CLK. Mesenchymal stromal cells as a choice for spinal cord injury treatment. Neuroimmuno/ Neuroinflammation 2020;7:1-12. http://dx.doi.org/10.20517/2347-8659.2019.009

Received: 25 Aug 2019 First Decision: 11 Oct 2019 Revised: 25 Dec 2019 Accepted: 2 Jan 2020 Published: 21 Mar 2020

Science Editor: Swapan Ray Copy Editor: Jing-Wen Zhang Production Editor: Tian Zhang

\begin{abstract}
Spinal cord injury $(\mathrm{SCl})$ is a serious clinical problem that affects approximately 17,500 new patients per year in the United States. The main causes of $\mathrm{SCl}$ are vehicle collisions, falls, violence (mainly gunshot wounds), and sports/recreational activities. The final severity of the damage results from primary and secondary mechanisms that begin at the time of injury and last for months after trauma. To reduce the extent of damage, several treatments have been proposed. This review summarizes results from several studies that have pointed to cell therapy as the main form of neuroregenerative treatment. Mesenchymal stromal cells (MSCs) are important candidates for tissue regeneration due to the release of bioactive factors, as well as antiapoptotic effects, scar inhibitors, and angiogenic effects. Studies have shown that MSCs act in various ways on injured tissue, such as immunomodulation of the inflamed environment, release of bioactive factors, restoration of axon myelin, prevention of neuronal apoptosis, and neuroregeneration. Current research using MSCs aims to prevent secondary injury, promote regeneration, and replace destroyed spinal cord tissue. This review presents information about the damage from primary and secondary events after $\mathrm{SCl}$, treatments usually used, and preclinical and clinical results aiming at the cell therapy using MSCs as a tissue regeneration strategy.
\end{abstract}

Keywords: Tissue regeneration, immunomodulation, neuroregeneration

\section{SPINAL CORD INJURY}

Spinal cord injury (SCI) is a very serious health problem, and available treatments are not capable of spinal cord regeneration ${ }^{[1]}$. SCI can lead to permanent neurological deficits, including motor and sensory disabilities, with high rates of physical disability and mortality. It can lead to serious damage to the physical and mental health of patients, which can cause serious socioeconomic issues ${ }^{[2,3]}$. According to the National

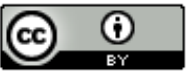

(C) The Author(s) 2020. Open Access This article is licensed under a Creative Commons Attribution 4.0 International License (https://creativecommons.org/licenses/by/4.0/), which permits unrestricted use, sharing, adaptation, distribution and reproduction in any medium or format, for any purpose, even commercially, as long as you give appropriate credit to the original author(s) and the source, provide a link to the Creative Commons license, and indicate if changes were made.

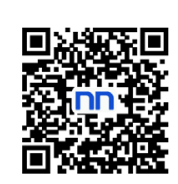




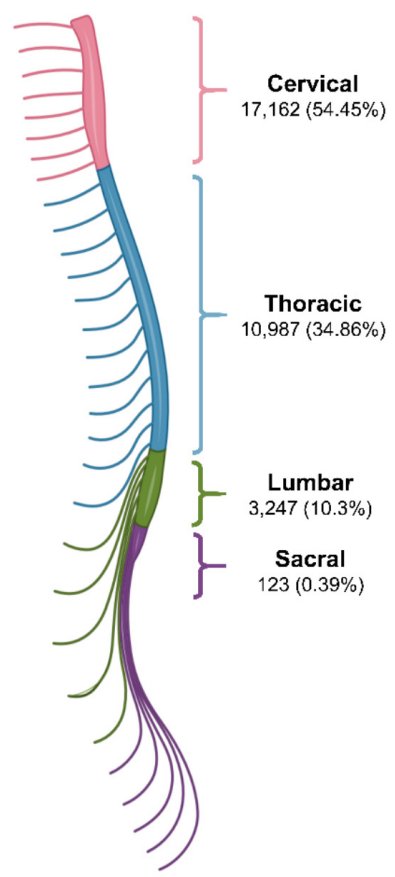

Figure 1. Number of cases of spinal cord injury according to trauma level. According to the National Spinal Cord Injury Statistical Center in the United States. The first region of the spine, the cervical region, is the most affected, accounting for more than half (54.45\%) of the total number of cases, followed by the thoracic $(34.86 \%)$ and lumbar $(10.3 \%)$ regions. The sacral region is the least injured, accounting for $0.39 \%$ of cases

Spinal Cord Injury Statistical Center, in the United States, there are approximately 17,500 new cases per year, of which $81 \%$ are male. The average age of new cases has changed since the 1970 s, from 29 to 43 years old. The main causes are vehicle collisions, falls, violence (mainly gunshot wounds), and sports or recreational activities ${ }^{[4]}$. In 2018, a survey conducted by the same institution about the frequency of SCI cases according to the level of the spinal cord showed that, of the total of 31,519 cases, $17,162(54.45 \%)$ are lesions in the cervical region, 10,987 (34.86\%) in the thoracic region, 3247 (10.3\%) in the lumbar region, and $123(0.39 \%)$ in the sacral region ${ }^{[4]}$ [Figure 1].

According to the National Spinal Cord Injury Statistical Center, in the United States, the first region of the spine, the cervical region, is the most affected, accounting for more than half (54.45\%) of the total number of cases, followed by the thoracic (34.86\%) and lumbar (10.3\%) regions, while the sacral region is the least injured, accounting for $0.39 \%$ of cases.

SCI results in disruption of the connection between the central nervous system and the rest of the body. Trauma, disease, and even spinal cord degeneration can compromise the sensory, motor, autonomic, and reflex functions of affected individuals, and only $0.4 \%$ of cases show complete recovery from their deteriorated functions ${ }^{[5]}$. The pathology of SCI results from two stages: (1) primary injury, which triggers damage to the spinal cord; and (2) secondary injury, characterized by events arising after the initial injury. Primary injury is usually the determining factor of the severity of the damage and the effects vary according to the affected site, which may be the cervical, thoracic, thoracolumbar, or sacral lumbar region ${ }^{[6]}$.

After trauma, secondary events such as ischemia, anoxia, and inflammation further compromise the injured tissue. There is the migration of inflammatory cells to the lesion site, which release inflammatory cytokines; formation of reactive oxygen species (ROS), which lead to DNA damage and protein oxidation; and mitochondrial malfunction due to ionic imbalance ${ }^{[6,7]}$. 
A

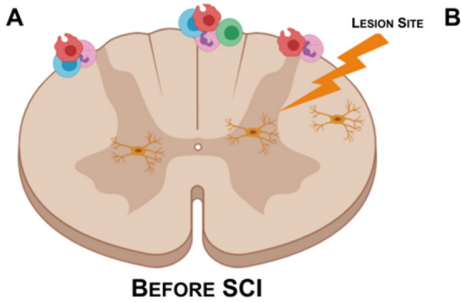

C

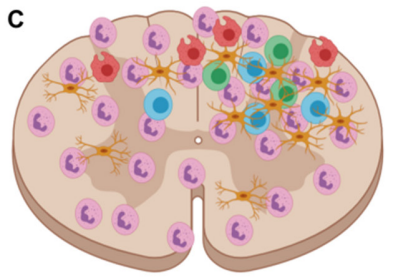

1 - 3 DAYS

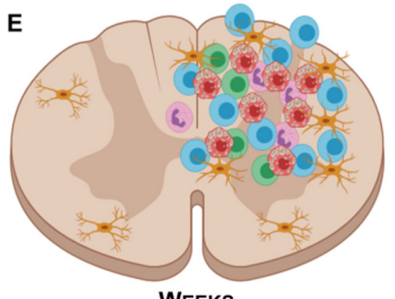

WEEKS

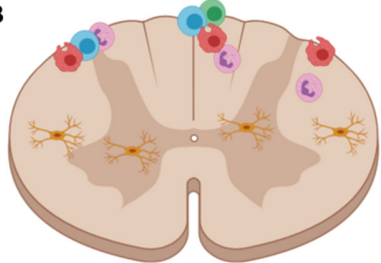

1 - 4 HOURS

D

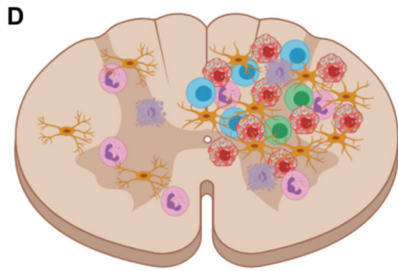

5 - 10 DAYS

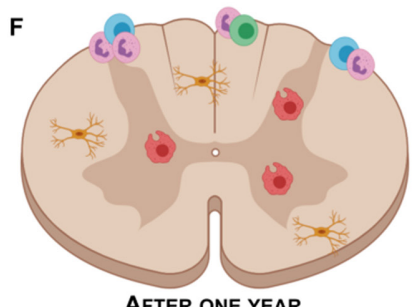

6. Neutrophil

Neutrophil (apoptosis)

Lymphocyte T CD4+

Lymphocyte T CD8+

Microglia (inactive)

Microglia (active)

Macrophage

Foamy macrophag

Figure 2. Immune cell migration in response to spinal cord injury (humans) (A-C): neutrophils migrate from vessels and perivascular region immediately after trauma, while lymphocytes, macrophages, and microglia migrate later. (D-F): the production of proinflammatory factors in response to the injured tissue results in tissue deterioration and damage spreading (secondary injury), which may compromise and determine the patient's grade of spinal cord injury recovery

Prior to the occurrence of SCI [Figure 2A], inflammatory cells, except for microglia, are found in the blood vessels and perivascular regions of the spinal cord. The microglia are distributed by gray and white matter. Mechanical damage to the injury (or trauma) results in immediate neuronal and glial death at the injury site. After the injury, an inflammatory process mediated by neutrophils, macrophages, lymphocytes, and microglia present in the vascular and medullary region develops. This secondary process leads to late deterioration of the spinal cord, resulting in worsening of the lesion condition. Immediately after injury, there is immediate neutrophil extravasation [Figure $2 \mathrm{~B}$ ] to the medulla, followed by late migration [Figure $2 \mathrm{C}$ ] of lymphocytes and macrophages to the lesion site ${ }^{[8,9]}$. The microglia are activated [Figure $2 \mathrm{C}$ ] and shorten and thicken their branches and migrate to the site of injury. Inactivated microglia remain in uninjured regions. During this period, there is production and release of proinflammatory factors (mainly activated microglia and macrophages), such as TNF- $\alpha$ and IL- $6 \beta$, as well as proteases and lysosomal enzymes. The inflammatory environment promotes the spread of damage, inducing cell death and preventing any spontaneous spinal cord regeneration ${ }^{[10,11]}$. Within 5-10 days [Figure 2D], neutrophils enter apoptosis, while macrophages and microglia proliferate in the lesion region. After a few weeks [Figure $2 \mathrm{E}$ ], the number of $\mathrm{CD} 8+, \mathrm{CD} 4+$, and $\mathrm{T}$ lymphocytes increases in the vessels of the injured region and the macrophage/ microglial population remains in large numbers. The few remaining neutrophils accumulate in the necrotic region. One year after the injury [Figure $2 \mathrm{~F}$ ], neutrophils and lymphocytes are found in the intravascular region. The microglia remain in the region of white matter in their inactivated form, while macrophages are found in the gray matter ${ }^{[8-11]}$ [Figure 2].

Secondary events mainly lead to neuron necrosis and apoptosis, which occur in the first hours after trauma ${ }^{[6,7]}$. At the same time, the body tries to prevent the injury from becoming more serious. In this 
sense, repair cells act and try to reverse the damage caused, expressing factors responsible for the formation of new vessels, eliminating cell debris, and remodeling damaged neurons ${ }^{[5]}$.

Treatment of the injury is limited by the low regenerative potential of the central nervous system, but spinal cord plasticity may support the recovery of some lost mechanisms after the injury. Spinal cord plasticity is related to factors such as synaptic reorganization, axonal sprouting, and neurogenesis ${ }^{[12]}$. There is little evidence of spontaneous axon regeneration after SCI but there is evidence for axonal sprouting as synaptic compensation. Regeneration is the growth of new axons, while sprouting involves the growth of collateral branches of the fibers. Due to the formation of a glial scar, which is a physical and chemical barrier to axonal regeneration, axonal sprouting is an alternative found because it can occur around a glial scar. To support SCI repair, studies have shown that functional exercise, neurotrophic factors, and cell therapy can effectively improve spinal cord neural plasticity response ${ }^{[12,13]}$.

\section{TREATMENTS}

After SCI, mammals are unable to regenerate nervous tissue, which can lead to lifelong disability ${ }^{[14]}$. Some treatments may be used after SCI to try to reduce side effects and protect injured nerve tissue. Decompression surgery is one of the treatments used to relieve pressure, reducing hypoxia and ischemia caused by edema and hemorrhage ${ }^{[15,16]}$. Studies have shown that patients who underwent decompression surgery before $24 \mathrm{~h}$ after SCI showed an improvement compared to patients who underwent surgery more than $24 \mathrm{~h}$ after SCI ${ }^{[16-18]}$. Fehlings et al. ${ }^{[17]}$ showed that more than half of the patients who underwent surgery (before or after $24 \mathrm{~h}$ ) had at least one grade of improvement on the American Spinal Injury Association Impairment Scale (AIS) without statistical difference between the groups. However, a higher percentage of patients had two or three grade improvement on the AIS scale in the group who underwent surgery before $24 \mathrm{~h}$ after 6 months of follow-up. Sewell et al. ${ }^{[18]}$ observed that patients with spinal cord injury (cervical level) who underwent surgery before and after $24 \mathrm{~h}$ showed no neurological improvement on the AIS scale with significant difference after 6 months of follow-up. However, there is a tendency for improvement in patients with early surgery, particularly in patients experiencing > 2-grade AIS improvement.

Another commonly used treatment after SCI is the intravenous application of methylprednisolone sodium succinate (MPSS). The central MPSS effect on SCI is the inhibition of posttraumatic lipid peroxidation occurring in neurons and blood vessels, directly compromising the function and integrity of neuronal and axonal membranes, causing microvascular damage and secondary ischemia that indirectly contribute to secondary neuronal injury. In addition to inhibiting lipid peroxidation, MPSS inhibits post-traumatic spinal cord ischemia, supports aerobic energy metabolism, and attenuates the neurofilaments loss ${ }^{[19,20]}$. However, the use of MPSS is not a consensus among professionals, because, even with improvement when applied up to eight hours after injury, this drug can cause gastrointestinal bleeding and infection ${ }^{[16,21]}$. Due to these associated complications, MPSS should be used with caution.

Neuroprotective agents are also a treatment option for spinal cord injury. These agents aim to prevent neuronal cell death by reducing side events that result in cell dysfunction and death ${ }^{[16,22]}$. Many of these neuroprotective agents have been studied, but without positive results for thoracic spinal cord injury patients $^{[23,24]}$. Riluzole, a sodium channel blocker, and hypothermia, which decreases central nervous system metabolism, have been shown to be effective neuroprotective agents for the treatment of spinal cord injury ${ }^{[16,25-27]}$. Mu et al. ${ }^{[28]}$ associated riluzole and MPSS in rats with spinal cord injury. The combined treatment preserved the tissue at the epicenter of the lesion but did not have a clear effect on the myelination index. The results of this study clearly demonstrate the potential beneficial effects of a combined approach in treating spinal cord injury. 
Electroacupuncture/electrostimulation is another treatment that has long been used in spinal cord injury therapy and has been shown to inhibit inflammation, promote the secretion of neurotrophic factors, and reduce secondary injuries ${ }^{[2,30]}$. Chen et al. ${ }^{[31]}$ performed electroacupuncture on rats with spinal cord injury and found that this treatment is effective to prevent oligodendrocyte apoptosis and to improve functional recovery after spinal cord injury. Krueger et al. ${ }^{[32]}$ performed the association of electrostimulation with mesenchymal stromal cells derived from adipose tissue in dogs with SCI and observed improvement, but without statistical difference between the associated treatments (electrostimulation and MSCs) and isolated.

There are many studies developing different techniques to assist the recovery of spinal cord injury patients. These studies aim to combat the primary or secondary events of the injury, aiming at patient improvement, but without regenerating the nervous tissue. Cell-based therapy is the only promising treatment aimed at regeneration. Many cell types from different sources and infusion pathways have been studied or are being evaluated in ongoing studies.

\section{STROMAL CELLS THERAPY}

Cell therapy brought the promise of regenerating tissue after SCI, although the mechanism by which this type of cell therapy achieves neurological recovery have not yet been fully explained. Adult stem cells, such as MSCs, are stromal cells with potential self-renovation, multiple lineage differentiation, and immunomodulatory potential ${ }^{[33]}$. MSCs are major candidates for tissue regeneration due to release of bioactive factors, as well as anti-apoptotic, scar inhibitor, and angiogenic effects ${ }^{[34]}$. These cells also have the potential for differentiation into various adult cell types, including neurons ${ }^{[3,36]}$. The main source of MSCs is bone marrow, but other sources such as adipose tissue and umbilical cord, which are easily collected tissues, are also being used in preclinical and clinical studies. Following MSC transplantation, several repair processes occur, including: (1) the release of neurotrophic factors that may prevent nerve degeneration and apoptosis, as well as support neurogenesis, axonal growth, remyelination, and cellular metabolism; (2) reduction of neuroinflammation because MSCs can secrete a variety of soluble molecules, such as antiinflammatory cytokines; (3) induction of angiogenesis, an important process by which new vasculature sprouts from pre-existing blood vessels; and (4) activation of endogenous spinal cord mechanisms capable of restoring some previously lost neurological functions ${ }^{[37-39]}$ [Figure 3].

Although the precise mechanism by which MSCs transplantation promotes functional recovery after SCI is still unclear, it is widely accepted that most benefits of MSCs transplanted rely on the secretion of different factors and biomolecules ${ }^{[40]}$. MSCs release cytokines that may be neuroprotective and neuroregenerative. Some cytokines, e.g., neurotrophic factor, monocyte chemoattractant protein-1, and granulocytemacrophage colony stimulating factor, play a role in neuroprotection; induce monocyte recruitment during inflammation, enhancing myelin debris clearance in central nervous system injuries; and inhibit apoptosis of neuronal cells and gliosis after SCI ${ }^{[41]}$. Other neurotrophic factors expressed by bone marrow derived mesenchymal stromal cell (BM-MSC) such as brain derived neurotrophic factor, glial-derived neurotrophic factor, and nerve growth factor can assist nervous tissue neuroregeneration including the formation of new synapses and myelination and promote axonal regeneration and functional recovery after $\mathrm{SCI}^{[2,43]}$.

MSCs also reduce inflammation, which is a secondary event after trauma. These cells change the inflammatory profile to the anti-inflammatory one, which could have a beneficial effect on functional recovery after $\mathrm{SCI}^{[42]}$. Transplantation of MSCs also reduces the expression of glial scar marker (GFAP), a characteristic compatible with a resolutive inflammatory reaction ${ }^{[42]}$, and increases the expression of Treggene $^{[44]}$.

Among the molecules secreted by MSCs, pro-angiogenic factors such as vascular endothelial growth factor (VEGF) are essential for repair of damaged tissue. VEGF/PDGF (platelet-derived growth factor) stimulated 


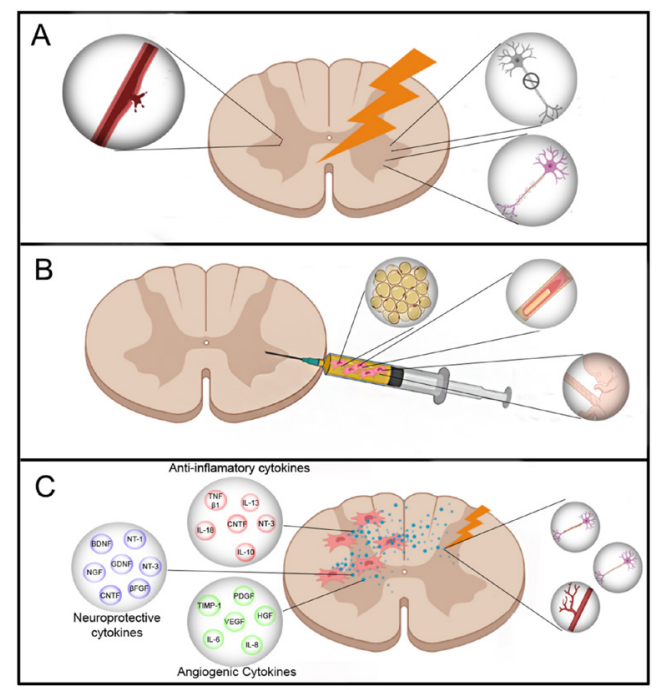

Figure 3. A: following injury, trauma and ruptured blood vessels result in ischemia, anoxia, and inflammation. This environment leads to neuronal death and degeneration; B: the infusion of MSCs can be done in different locations. There is still disagreement regarding the number of cells and infusions, but MSCs from different sources can be used for treatment (umbilical cord, adipose tissue, and bone marrow); C: after infusion, MSCs change the injured environment by releasing anti-inflammatory (TNF- $\beta 1$, IL-13, IL-18, CNTF, NT-3, and IL-10), neuroprotective (BDNF, GDNF, NGF, NT-1, NT-3, CNTF, and bFGF), and angiogenic cytokines (TIMP-1, VEGF, HGF, PDGF, IL-6, and IL-8). Cell survival, remyelination, and vascular repair can also be observed. MSCs: mesenchymal stromal cells; TNF- $\beta 1$ : transforming growth factor $\beta 1$; IL-13: interleukin 13; IL-18: interleukin 18; CNTF: ciliary neurotrophic factor; IL-10: interleukin 10; BDNF: brain-derived neurotrophic factor; GDNF: glial cell-derived neurotrophic factor; NGF: nerve growth factor; NT-1: neurotrophin 1; NT-3: neurotrophin 3; bFGF: basic fibroblast growth factor; TIMP-1: tissue inhibitor of metalloproteinase-1; VEGF: vascular endothelial growth factor; HGF: hepatocyte growth factor; PDGF: platelet-derived growth factor; IL-6: interleukin 6; IL-8: interleukin 8

angiogenesis results in a higher blood vessel density at the injured site, lesion size reduction, and white matter sparing with functional outcome after $\mathrm{SCI}^{[45]}$.

Although most studies showed evidence that MSCs most likely act through their secretions (paracrine effect $)^{[46-48]}$ and not via their own integration/differentiation within the host tissue, some authors have reported the potential for MSCs transdifferentiation in cells of the nervous system and have shown that, after infusion into the spinal cord, these cells possibly promote regeneration of neurons because they have neuronal markers ${ }^{[49-52]}$. In vitro studies have shown that BM-MSC possess an intrinsic capacity to differentiate into neural-like and glial-like cells and express nestin, $\beta I I I-t u b u l i n$, neurofilaments, neuronspecific enolase, and glial fibrillary acidic protein (GFAP) ${ }^{[53-55]}$.

A better understanding of the mechanisms underlying the regenerative effects of stromal/progenitor cells in the nervous system is essential for development of future cell-based therapies to treat SCI in humans.

Despite a lot of effort in recent years to develop new therapies using stromal cells to treat central nervous system trauma, there is no consensus on the cell type, source, number of cells, infusion pathways, and number of infusions suitable for achieving this goal ${ }^{[56]}$.

Adult stromal cells have been used in preclinical research and clinical studies. These studies demonstrate how research uses different strategies for treating spinal cord injury using different sources of MSCs, multiple cell infusion pathways, and various models of SCI. Various types of SCI can be treated with cell therapy using MSCs, including even in patients with complete SCI $^{[57-59]}$. MSCs can be transplanted intrathecally, intramedullary, intravenously, or intraarterially with different MSC sources (bone marrow, adipose tissue, umbilical cord blood, skin, and dental tissues) ${ }^{[5]}$ [Tables 1 and 2]. 


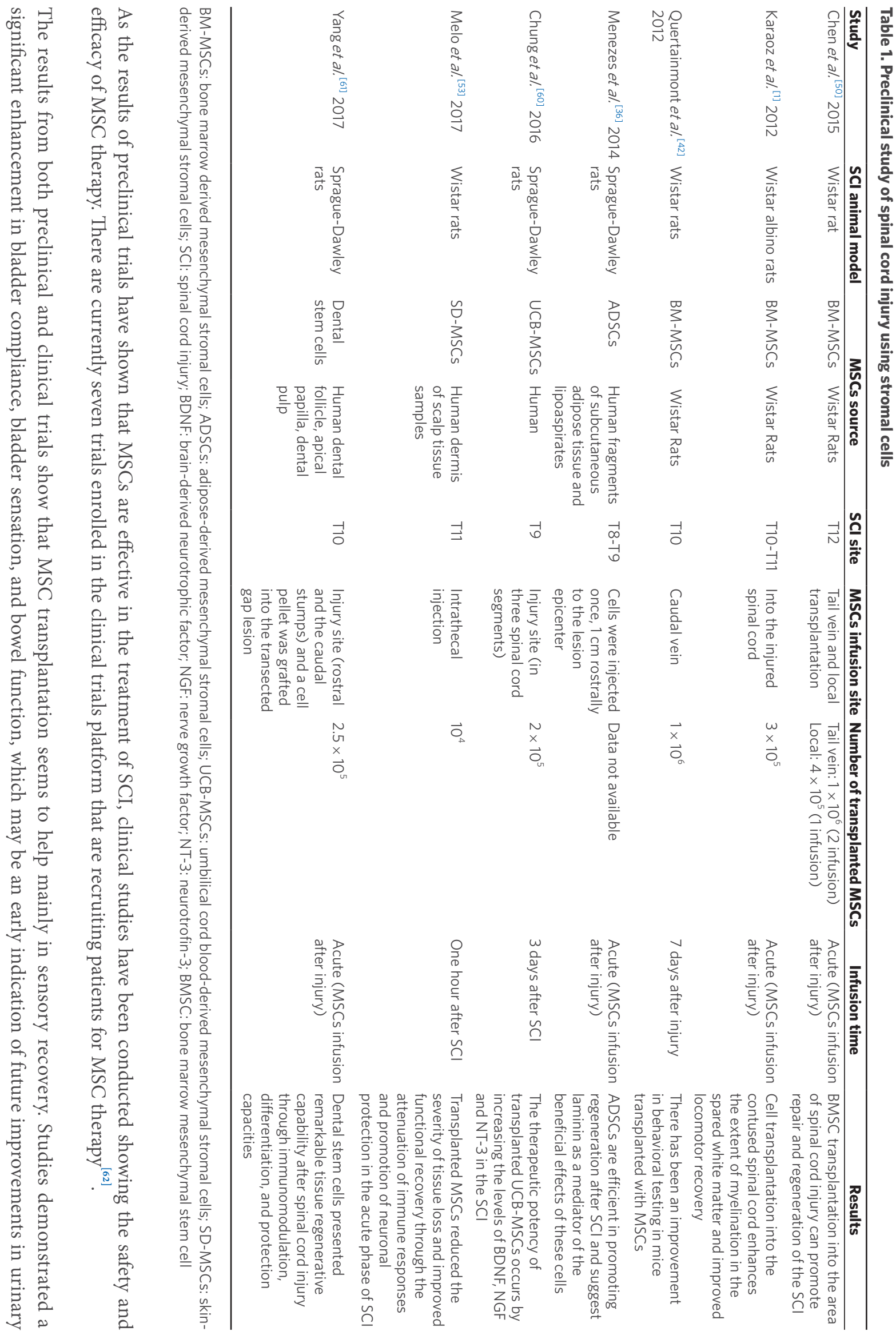




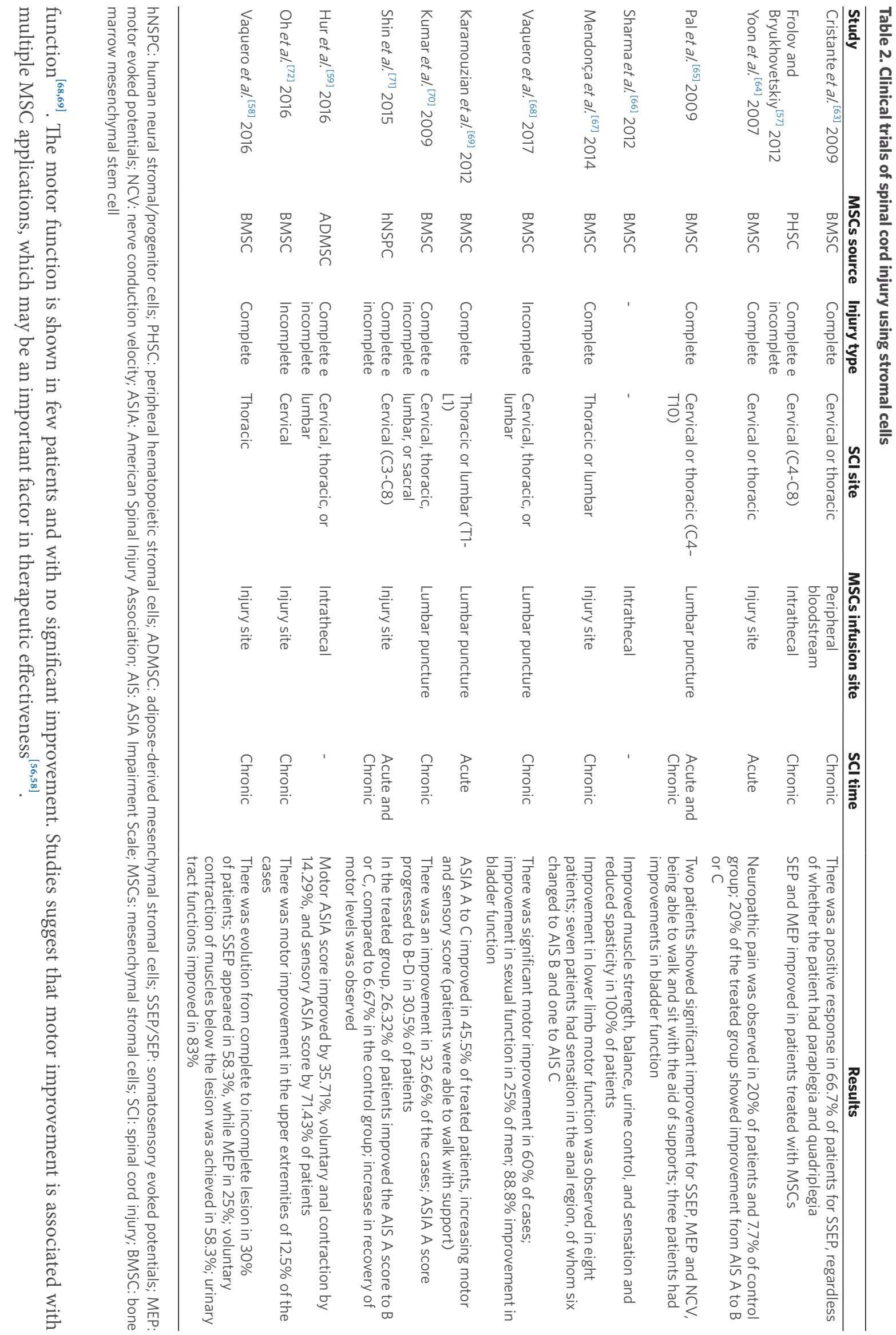




\section{CHALLENGES AND PERSPECTIVES}

SCI has been extensively studied and its mechanism is already known. Many preclinical and clinical studies have already been performed using drugs associated with SCI, neurotrophic factors, and stem cells. In cell therapy, several cell types and sources have already been tested. Embryonic stem cells involve ethical issues and chromosomal instability that make them difficult to use in clinical trials. MSCs have emerged as an alternative, but with a more limited differentiation capacity. Studies have already demonstrated the effectiveness of these MSCs in SCI, but the next challenges are to identify the type of cell that has the most appropriate potential to support SCI regeneration and develop an infusion methodology that can overcome the hostile microenvironment and facilitate MSCs delivery in damaged neural tissue. Understanding how the reorganization of injured neural tissues associated with MSCs is also crucial for restoring neural function but remains largely unknown and needs further clarification. While addressing these challenges, it is still necessary to maintain the safety of patients involved in the studies, as the mechanisms of action of stem cells are not yet fully described.

\section{CONCLUSION}

SCI is a serious disease which generates disability with unknown cure. Different treatments have already been developed but none of them has tissue regeneration as a result. Mesenchymal stromal cells seem to be a promising alternative because, in addition to tissue regeneration, they can act to improve the inflamed environment through immunomodulation, release of bioactive factors, and restoration of axon myelin. Preclinical and clinical research studies will enable the definition of the best source of MSCs, cell number, route of infusion, and number of infusions that may lead to clinical improvement for SCI patients.

Animal model and human clinical studies have shown the regenerative and neuroprotective potential of MSCs from different sources. In addition, it is interesting to note the absence of adverse effects after MSCs infusion. MSCs emerge as a new alternative therapy because they are not limited by the time of injury, showing promising results in patients with acute and chronic lesions, or by the type of injury, resulting in improvements in patients with complete and incomplete SCI.

\section{DECLARATIONS}

\section{Authors' Contributions}

Designed of the work, summarized the references and wrote the manuscript: Fracaro L

Summarized the references, wrote the manuscript, prepared the figures: Zoehler B

Discussed paper writing and revised the manuscript: Rebelatto CLK

\section{Availability of data and materials}

Not applicable.

Financial support and sponsorship

None.

\section{Conflicts of interest}

All authors declared that there are no conflicts of interest.

\section{Ethical approval and consent to participate}

Not applicable.

\section{Consent for publication}

Not applicable. 


\section{Copyright}

(c) The Author(s) 2020.

\section{REFERENCES}

1. Karaoz E, Kabatas S, Duruksu G, Okcu A, Subasi C, et al. Reduction of lesion in injured rat spinal cord and partial functional recovery of motility after bone marrow derived mesenchymal stem cell transplantation. Turk Neurosurg 2012;22:207-17.

2. Yi XM, Chen Y, Tu GJ. Neuregulin-1 impacting bone marrow mesenchymal stem cell migration is conducive to functional recovery following spinal cord injury. Mol Med Rep 2019;20:41-8.

3. Jain NB, Ayers GD, Peterson EN, Harris MB, Morse L, et al. Traumatic spinal cord injury in the United States, 1993-2012. Jama 2015;313:2236-43.

4. Center NSCIS. Facts and Figures at a Glance. University of Alabama at Birmingham 2018.

5. Shende P, Subedi M. Pathophysiology, mechanisms and applications of mesenchymal stem cells for the treatment of spinal cord injury. Biomed Pharmacother 2017;91:693-706.

6. Ahuja CS, Nori S, Tetreault L, Wilson J, Kwon B, et al. Traumatic spinal cord injury-repair and regeneration. Neurosurgery 2017;80:S9-22.

7. Kjell J, Olson L. Rat models of spinal cord injury: from pathology to potential therapies. Dis Model Mech 2016;9:1125-37.

8. Fleming JC, Norenberg MD, Ramsay DA, Dekaban GA, Marcillo AE, et al. The cellular inflammatory response in human spinal cords after injury. Brain 2006;129:3249-69.

9. Beattie MS. Inflammation and apoptosis: linked therapeutic targets in spinal cord injury. Trends Mol Med 2004;10:580-3.

10. Okada S. The pathophysiological role of acute inflammation after spinal cord injury. Inflamm Regen 2016;36:20.

11. Rust R, Kaiser J. Insights into the dual role of inflammation after spinal cord injury. J Neurosci 2017;37:4658-60.

12. Liu J, Yang X, Jiang L, Wang C, Yang M. Neural plasticity after spinal cord injury. Neural Regene Res 2012;7:386-91.

13. Darian-Smith C. Synaptic plasticity, neurogenesis, and functional recovery after spinal cord injury. Neuroscientist 2009;15:149-65.

14. Qu J, Zhang H. Roles of mesenchymal stem cells in spinal cord injury. Stem Cells Int 2017;2017:5251313.

15. Ahuja CS, Martin AR, Fehlings M. Recent advances in managing a spinal cord injury secondary to trauma. F1000Res 2016;5.

16. Rouanet C, Reges D, Rocha E, Gagliardi V, Silva GS. Traumatic spinal cord injury: current concepts and treatment update. Arq Neuropsiquiatr 2017;75:387-93.

17. Fehlings MG, Vaccaro A, Wilson JR, Singh A, W Cadotte D, et al. Early versus delayed decompression for traumatic cervical spinal cord injury: results of the Surgical Timing in Acute Spinal Cord Injury Study (STASCIS). PLoS One 2012;7:e32037.

18. Sewell MD, Vachhani K, Alrawi A, Williams R. Results of early and late surgical decompression and stabilization for acute traumatic cervical spinal cord injury in patients with concomitant chest injuries. World Neurosurg 2018;118:e161-5.

19. Wilson JR, Forgione N, Fehlings MG. Emerging therapies for acute traumatic spinal cord injury. CMAJ 2013;185:485-92.

20. Hall ED, Springer JE. Neuroprotection and acute spinal cord injury: a reappraisal. NeuroRx 2004;1:80-100.

21. Bracken MB, Shepard MJ, Holford TR, Leo-Summers L, Aldrich EF, et al. Administration of methylprednisolone for 24 or 48 hours or tirilazad mesylate for 48 hours in the treatment of acute spinal cord injury. Results of the Third National Acute Spinal Cord Injury Randomized Controlled Trial. National Acute Spinal Cord Injury Study. JAMA 1997;277:1597-604.

22. Schapira AHV. Chapter 18 - Neuroprotection in Parkinson's Disease. In: Schapira AHV, Samuels MA, editors. Blue Books of Neurology: Butterworth-Heinemann; 2010. pp. 301-20.

23. Casha S, Zygun D, McGowan MD, Bains I, Yong VW, et al. Results of a phase II placebo-controlled randomized trial of minocycline in acute spinal cord injury. Brain 2012;135:1224-36.

24. Ulndreaj A, Badner A, Fehlings MG. Promising neuroprotective strategies for traumatic spinal cord injury with a focus on the differential effects among anatomical levels of injury. F1000Res 2017;6:1907.

25. Wang J, Pearse DD. Therapeutic hypothermia in spinal cord injury: the status of its use and open questions. Int J Mol Sci 2015; $16: 16848-79$.

26. Levi AD, Green BA, Wang MY, Dietrich WD, Brindle T, et al. Clinical application of modest hypothermia after spinal cord injury. J Neurotrauma 2009;26:407-15.

27. Grossman RG, Fehlings MG, Frankowski RF, Burau KD, Chow DS, et al. A prospective, multicenter, phase I matched-comparison group trial of safety, pharmacokinetics, and preliminary efficacy of riluzole in patients with traumatic spinal cord injury. J Neurotrauma 2014;31:239-55.

28. $\mathrm{Mu} \mathrm{X}$, Azbill RD, Springer JE. Riluzole and methylprednisolone combined treatment improves functional recovery in traumatic spinal cord injury. J Neurotrauma 2000;17:773-80.

29. Chen XM, Xu J, Song JG, Zheng BJ, Wang XR. Electroacupuncture inhibits excessive interferon-gamma evoked up-regulation of P2X4 receptor in spinal microglia in a CCI rat model for neuropathic pain. Br J Anaesth 2015;114:150-7.

30. Zhang YT, Jin H, Wang JH, Wen LY, Yang Y, et al. Tail nerve electrical stimulation and electro-acupuncture can protect spinal motor neurons and alleviate muscle atrophy after spinal cord transection in rats. Neural plasticity 2017;2017:7351238.

31. Chen W, Wu Y. Electro-acupuncture (EA) mediated downregulation of microRNA-181a alleviates spinal cord neuronal apoptosisby inhibition of p38 MAPK pathway. Int J Clin Exp Med 2017;10:7806-15.

32. Krueger E, Magri LMS, Botelho AS, Bach FS, Rebellato CLK, et al. Effects of low-intensity electrical stimulation and adipose derived stem cells transplantation on the time-domain analysis-based electromyographic signals in dogs with SCI. Neurosci Lett 2019;696:38-45.

33. Caplan AI. Adult mesenchymal stem cells for tissue engineering versus regenerative medicine. J Cell Physiol 2007;213:341-7.

34. Caplan AI. Why are MSCs therapeutic? New data: new insight. J Pathol 2009;217:318-24.

35. Scuteri A, Miloso M, Foudah D, Orciani M, Cavaletti G, et al. Mesenchymal stem cells neuronal differentiation ability: a real 
perspective for nervous system repair? Curr Stem Cell Res Ther 2011;6:82-92.

36. Menezes K, Nascimento MA, Goncalves JP, Cruz AS, Lopes DV, et al. Human mesenchymal cells from adipose tissue deposit laminin and promote regeneration of injured spinal cord in rats. PLoS One 2014;9:e96020.

37. Cofano F, Boido M, Monticelli M, Zenga F, Ducati A, et al. Mesenchymal stem cells for spinal cord injury: current options, limitations, and future of cell therapy. Int J Mol Sci 2019;20.

38. Paradisi M, Alviano F, Pirondi S, Lanzoni G, Fernandez M, et al. Human mesenchymal stem cells produce bioactive neurotrophic factors: source, individual variability and differentiation issues. Int J Immunopathol Pharmacol 2014;27:391-402.

39. Garbossa D, Boido M, Fontanella M, Fronda C, Ducati A, et al. Recent therapeutic strategies for spinal cord injury treatment: possible role of stem cells. Neurosurg Rev 2012;35:293-311.

40. Martín-Martín Y, Fernández-García L, Sanchez-Rebato MH, Marí-Buyé N, Rojo FJ, et al. Evaluation of neurosecretome from mesenchymal stem cells encapsulated in silk fibroin hydrogels. Sci Rep 2019;9:8801.

41. Bouhy D, Malgrange B, Multon S, Poirrier AL, Scholtes F, et al. Delayed GM-CSF treatment stimulates axonal regeneration and functional recovery in paraplegic rats via an increased BDNF expression by endogenous macrophages. FASEB J 2006;20:1239-41.

42. Quertainmont R, Cantinieaux D, Botman O, Sid S, Schoenen J, et al. Mesenchymal stem cell graft improves recovery after spinal cord injury in adult rats through neurotrophic and pro-angiogenic actions. PLoS One 2012;7:e39500.

43. Milczarek O, Jarocha D, Starowicz-Filip A, Kwiatkowski S, Badyra B, et al. Multiple autologous bone marrow-derived CD271(+) mesenchymal stem cell transplantation overcomes drug-resistant epilepsy in children. Stem Cells Transl Med 2018;7:20-33.

44. Fu Q, Liu Y, Liu X, Zhang Q, Chen L, et al. Engrafted peripheral blood-derived mesenchymal stem cells promote locomotive recovery in adult rats after spinal cord injury. Am J Transl Res 2017;9:3950-66.

45. Sundberg LM, Herrera JJ, Narayana PA. Effect of vascular endothelial growth factor treatment in experimental traumatic spinal cord injury: in vivo longitudinal assessment. J Neurotrauma 2011;28:565-78.

46. de Almeida FM, Marques SA, Ramalho Bdos S, Massoto TB, Martinez AM. Chronic spinal cord lesions respond positively to tranplants of mesenchymal stem cells. Restor Neurol Neurosci 2015;33:43-55.

47. Chudickova M, Vackova I, Machova Urdzikova L, Jancova P, Kekulova K, et al. The effect of wharton jelly-derived mesenchymal stromal cells and their conditioned media in the treatment of a rat spinal cord injury. Int J Mol Sci 2019;20.

48. Hakim R, Covacu R, Zachariadis V, Frostell A, Sankavaram SR, et al. Mesenchymal stem cells transplanted into spinal cord injury adopt immune cell-like characteristics. Stem Cell Res Ther 2019;10:115.

49. Lee KH, Suh-Kim H, Choi JS, Jeun SS, Kim EJ, et al. Human mesenchymal stem cell transplantation promotes functional recovery following acute spinal cord injury in rats. Acta Neurobiol Exp (Wars) 2007;67:13-22.

50. Chen YB, Jia QZ, Li DJ, Sun JH, Xi S, et al. Spinal cord injury in rats treated using bone marrow mesenchymal stem-cell transplantation. Int J Clin Exp Med 2015;8:9348-54.

51. Cui B, Li E, Yang B, Wang B. Human umbilical cord blood-derived mesenchymal stem cell transplantation for the treatment of spinal cord injury. Exp Ther Med 2014;7:1233-6.

52. Gao S, Guo X, Zhao S, Jin Y, Zhou F, et al. Differentiation of human adipose-derived stem cells into neuron/motoneuron-like cells for cell replacement therapy of spinal cord injury. Cell Death Dis 2019;10:597.

53. Melo FR, Bressan RB, Forner S, Martini AC, Rode M, et al. Transplantation of human skin-derived mesenchymal stromal cells improves locomotor recovery after spinal cord injury in rats. Cell Mol Neurobiol 2017;37:941-7.

54. Ma K, Fox L, Shi G, Shen J, Liu Q, et al. Generation of neural stem cell-like cells from bone marrow-derived human mesenchymal stem cells. Neurol Res 2011;33:1083-93.

55. Blecker D, Elashry MI, Heimann M, Wenisch S, Arnhold S. New insights into the neural differentiation potential of canine adipose tissue-derived mesenchymal stem cells. Anat Histol Embryol 2017;46:304-15.

56. Thuret S, Moon LDF, Gage FH. Therapeutic interventions after spinal cord injury. Nat Rev Neurosci 2006;7:628.

57. Frolov AA, Bryukhovetskiy AS. Effects of hematopoietic autologous stem cell transplantation to the chronically injured human spinal cord evaluated by motor and somatosensory evoked potentials methods. Cell Transplant 2012;21:49-55.

58. Vaquero J, Zurita M, Rico MA, Bonilla C, Aguayo C, et al. An approach to personalized cell therapy in chronic complete paraplegia: The Puerta de Hierro phase I/II clinical trial. Cytotherapy 2016;18:1025-36.

59. Hur JW, Cho TH, Park DH, Lee JB, Park JY, et al. Intrathecal transplantation of autologous adipose-derived mesenchymal stem cells for treating spinal cord injury: a human trial. J Spinal Cord Med 2016;39:655-64.

60. Chung HJ, Chung WH, Lee JH, Chung DJ, Yang WJ, et al. Expression of neurotrophic factors in injured spinal cord after transplantation of human-umbilical cord blood stem cells in rats. J Vet Sci 2016;17:97-102.

61. Yang C, Li X, Sun L, Guo W, Tian W. Potential of human dental stem cells in repairing the complete transection of rat spinal cord. J Neural Eng 2017;14:026005.

62. ClinicalTrials.gov [Internet]. Bethesda (MD): National Library of Medicine (US), National Institutes of Health; 2000 - [cited 2019 Aug 25]. Available from https://clinicaltrials.gov/ct2/home [Last accessed on 20 Jan 2020]

63. Cristante AF, Barros-Filho TE, Tatsui N, Mendrone A, Caldas JG, et al. Stem cells in the treatment of chronic spinal cord injury: evaluation of somatosensitive evoked potentials in 39 patients. Spinal Cord 2009;47:733-8.

64. Yoon SH, Shim YS, Park YH, Chung JK, Nam JH, et al. Complete spinal cord injury treatment using autologous bone marrow cell transplantation and bone marrow stimulation with granulocyte macrophage-colony stimulating factor: phase I/II clinical trial. Stem Cells 2007;25:2066-73.

65. Pal R, Venkataramana NK, Bansal A, Balaraju S, Jan M, et al. Ex vivo-expanded autologous bone marrow-derived mesenchymal stromal cells in human spinal cord injury/paraplegia: a pilot clinical study. Cytotherapy 2009;11:897-911.

66. Sharma A, Gokulchandran N, Chopra G, Kulkarni P, Lohia M, et al. Administration of autologous bone marrow-derived mononuclear cells in children with incurable neurological disorders and injury is safe and improves their quality of life. Cell Transplant 2012;21 
Suppl 1:S79-90.

67. Mendonça MVP, Larocca TF, de Freitas Souza BS, Villarreal CF, Silva LFM, et al. Safety and neurological assessments after autologous transplantation of bone marrow mesenchymal stem cells in subjects with chronic spinal cord injury. Stem Cell Res Ther $2014 ; 5: 126$

68. Vaquero J, Zurita M, Rico MA, Bonilla C, Aguayo C, et al. Repeated subarachnoid administrations of autologous mesenchymal stromal cells supported in autologous plasma improve quality of life in patients suffering incomplete spinal cord injury. Cytotherapy 2017;19:349-59

69. Karamouzian S, Nematollahi-Mahani SN, Nakhaee N, Eskandary H. Clinical safety and primary efficacy of bone marrow mesenchymal cell transplantation in subacute spinal cord injured patients. Clin Neurol Neurosurg 2012;114:935-9.

70. Kumar AA, Kumar SR, Narayanan R, Arul K, Baskaran M. Autologous bone marrow derived mononuclear cell therapy for spinal cord injury: a phase I/II clinical safety and primary efficacy data. Exp Clin Transplant 2009;7:241-8.

71. Shin JC, Kim KN, Yoo J, Kim IS, Yun S, et al. Clinical trial of human fetal brain-derived neural stem/progenitor cell transplantation in patients with traumatic cervical spinal cord injury. Neural Plast 2015;2015:630932.

72. Oh SK, Choi KH, Yoo JY, Kim DY, Kim SJ, et al. A phase III clinical trial showing limited efficacy of autologous mesenchymal stem cell therapy for spinal cord injury. Neurosurgery 2016;78:436-47. 